\title{
Thyroid Medullary Carcinoma in a Patient with HIV/AIDS
}

\author{
Metin ISIK' ${ }^{1}$, Asena GOKCAY ${ }^{2}$, Kadri ALTUNDAG ${ }^{2}$ \\ ${ }^{1}$ Ankara Numune Research an Training Hospital, Ankara, Department of Medical Oncology, Ankara, TURKEY \\ ${ }^{2}$ Hacettepe University Institute of Oncology, Department of Medical Oncology, Ankara, TURKEY
}

\begin{abstract}
According to the clinical trials HIV positivity does not increase the frequency of thyroid malignancies. We present a patient with HIV positivity and thyroid medullary carcinoma. To our knowledge this is the second case in the literature.
\end{abstract}

Keywords: HIV positive, Thyroid medullary carcinoma, AIDS

ÖZET

HIV/AIDS'li bir Olguda Medullar Tiroid Karsinomu

Klinik çalışmalara göre HIV pozitfliği tiroid malignansi sıklığını artırmamaktadır. HIV pozitif bir olguda gelişen tiroid medullar karsinomlu bir olguyu sunuyoruz. Bildiğimiz kadarıla bu olgu literatürdeki ikinci olgudur.

\section{INTRODUCTION}

Medullary thyroid carcinoma (MTC) is a rare primary thyroid carcinoma that makes up only $5-10 \%$ of all thyroid malignancies and is blamed for $13 \%$ of thyroid cancer related deaths. ${ }^{1}$ There are hereditary forms of MTC as a part of the multiple endocrine neoplasia (MEN) syndromes including MEN 2A and MEN 2B and also familial MTC (FMTC). ${ }^{2}$ At the time of diagnosis, sporadic MTC frequently present with distant metastasis involving cervical lymph nodes, lungs, liver, and/or bones, and this is the main cause of MTC-related deaths. ${ }^{3}$ Calcitonin and rearranged during transfection (RET) proto-oncogene tests enable the diagnosis of hereditary MTC in preclinical stage, but early detection is difficult. ${ }^{2}$ Nowadays, with the use of combination antiretroviral therapy (cART), malignancies have become the most frequent cause of death for HIV-infected patients. ${ }^{4}$ 
Indeed, infection by HIV is associated with a high risk of emergent high-grade systemic non-Hodgkin's lymphomas (NHLs) as Burkitt's and immunoblastic lymphomas, primary NHL of the central nerveous system, Kaposi's sarcoma, and invasive cervical cancer, and these are considered as AIDSdefining events according to the classification of the Centers for Disease Control and Prevention which was revised in $1993 .{ }^{5}$ There is epidemiological data that HIV/AIDS also increase malignancies like Hodgkin's disease, hepato-cellular carcinoma and others. ${ }^{6}$ But thyroid malignancies related to HIV/AIDS are rare and to our knowledge MTC in a patient with HIV/AIDS was reported only once before.?

\section{CASE}

Here, we present a 56 years old female patient who applied to our clinic with recurrent infections on May 2005. She had six episodes of infection in a year, 3 pneumonia attacks, 2 urinary tract infections and a sinusitis. On the routine laboratory examination the neutrophil count was $1200 / \mathrm{ml}$, and her husband had a diagnosis of HIV/AIDS, therefore a serology test for HIV/AIDS was done and she was diagnosed as HIV positive. Serum viral load was 22,100 copies $/ \mathrm{mL}$; the CD4 count was $345 / \mathrm{mm}^{3}$. Lamivudine, zidovudine and nevirapine combination therapy and vaccination for Streptococcus pneumoniae and hepatitis B was started and by this highly active antiretroviral therapy (HAART) she was doing well and the laboratory datas were within normal limits. On her routine control visit on June 2007 she had a complaint of swallowing difficulty and on the phisical examination a mass on both the left lobe of the thyroid was detected that was nearly 20 milimeters in diameter and also a lymphadenopathy was seen in left supraclavicular area nearly 15 milimeters in diameter. On the ultrasonographic evaluation this mass was reported to be $23 \times 21 \mathrm{~mm}$ in diameter including microcalcifications and the parenchyma of the gland was heterogeneous. A fine needle aspiration biopsy was done and atypical cells suspecting malignancy which was mostly compatiple with thyroid medullary carcinoma was reported. Therefore, a total thyroidectomy was done on July 2007. The pathological diagnosis was solitary throid medullary carcinoma 13 milimeters in diameter with one metastatic on the right paratrakeal region with characteristic amyloid deposition. The dyes for CEA (carcinoembryonic antigen), calcitonin and TTF-1 (thyroid transcription factor) revealed positive result. On the routine radiologic evaluation there were no distant metastasis so chemotherapy was not preferred. Currently, she comes to the routine control visits without metastasis or local recurrence, and the laboratory examinations for HIV/AIDS are within acceptable limits.

\section{DISCUSSION}

During the last 2 decades, because of the wide use of highly active antiretroviral therapy (HAART), both the rate of mortality and incidence of AIDSdefining opportunistic infections have dramatically decreased ${ }^{8.9}$ On the contrary, a new morbidity pattern has emerged including the malignancies, drug toxicity, co-infections (especially hepatitis $\mathrm{B} / \mathrm{C}$ ) or cardiovascular diseases. ${ }^{1,3,4}$ Malignancies are also one of the most frequent cause of hospitalization. ${ }^{4}$ The most frequent malignancies in these patients are; high-grade non-Hodgking's Lymphoma (NHL), primary NHL of the central nerveous system, Kaposi's sarcoma and invasive cervical cancer which are also named as AIDS-defining malignancies. ${ }^{5}$ Hodgking's lymphoma, lung cancer, anal cancer and hepatocellular carcinomas are the other malignancies that are 2-3 fold more diagnosed in the HIV-positive patients but are not named as AIDSdefining malignancies. ${ }^{4}$

Frisch et al, followed more than 300.000 HIV positive patients between 1978 and 1996 and reported that lip, kidney, eye tumors, testicular seminomas, leukemias, multiple myelomas and malign melanomas are also more frequent in the HIV-positive population. $^{10}$

Sam M. Mbulaiteye et al, reported the malignancy rates of 12607 patients in Uganda in 2005. Of all $378(2.99 \%)$ patients had a malignancy and 137 of them were AIDS defining malignancies. Also 2 patient had thyroid malignancies but the pathological subtypes were not stated."

To our knowledge no increase in thyroid malignancies have been described in the HIV-positive population. Thyroid malignancies are mostly papillary 
or follicular type and medullary carcinoma of the throid compose only $5-10 \%$ of all the thyroid malignancies. ${ }^{1}$ Medullary cancer of the thyroid originates from the parafollicular cells (also called C cells) of the thyroid and are known to be unrelated to radioactivity or thyroid stimulating hormon (TSH) activity. ${ }^{12}$ Sporadic MTC frequently present with distant metastasis involving cervical lymph nodes, lungs, liver, and/or bones, and this is the main cause of MTC-related deaths. ${ }^{3}$ As it was stated before the frequency of thyroid malignancies are not increased in HIV-positive population therefore most of the clinicians do not suspect or examine the patient routinely for thyroid malignancy.

Landriscina et al, pretended that reverse transcriptase inhibitors (RTI) as nevirapine, increase the expression of the receptors for TSH and also increases the expression of thyroglobuline and thyroid peroxidase genes. ${ }^{12}$ By this way RTIs can facilitate the onset of cell differentiation and down-regulate the cell proliferation. This mechanism may block the occurance of undifferentiated thyroid malignancies like medullary or anaplastic types and may also explain why medullary and anaplastic thyroid carcinomas are rarely diagnosed in patients with HIV/AIDS. On the other hand due to the increase of TSH by the usage of RTI the differentiated thyroid carcinomas like papillary and follicullar types may come out more easily. After the publication of this paper no new data proved the accuracy of this hypothesis during the 5 year period.

In conclusion, although thyroid medullary carcino$m a$ is very rare and the frequency does not increase in HIV positive patients it should be bear in mind that it may be seen.

\section{REFERENCES}

1 Hsieh $\mathrm{MH}$, Hsiao YL, Chang TC. Fine needle aspiration cytology stained with Riu's method in quicker diagnosis of medullary thyroid carcinoma. J Formos Med Assoc 106: 728-735, 2007.

2 Fialkowski EA, Moley JF. Current approaches to medullary thyroid carcinoma, sporadic and familial. J Surg Oncol 94: 737-747, 2006.

3 Schlumberger M, Carlomagno F, Baudin E, et al. New therapeutic approaches to treat medullary thyroid carcinoma. Nat Clin Pract Endocrinol Metab 4: 22-32, 2008.
4 Bonneta F, Chene G. Evolving epidemiology of malignancies in HIV. Curr Opin in Oncol 20: 534-540, 2008.

5 Centers for Disease Control and Prevention. 1993 revised classification system for HIV infection and expanded surveillance case definition for AIDS among adolescents and adults. MMWR 41: 1-19, 1992.

6 Ramírez-Olivencia G, Valencia-Ortega ME, Martin-Carbonero L, et al. Malignancies in HIV infected patients: Study of 139 cases. Med Clin (Barc) 133: 729-735, 2009.

7 Behrand M, von Wasielewski R, Brabant G. Simultaneous medullary and papillary micro-carcinoma of the thyroid in a patient with secondary hyper-parathyroidism. Endocrine pathol 13: 65-73, 2002.

8 Palella FJ Jr, Delaney KM, Moorman AC, et al. Declining morbidity and mortality among patients with advanced human immunodeficiency virus infection. HIV Outpatient Study Investigators. N Engl J Med 338: 853-860, 1998.

9 CASCADE Collaboration. Survival after introduction of HAART in people with known duration of HIV-1 infection. Lancet 355: 1158-1159, 2000.

10 Frisch M, Biggar RJ, Engels EA, Goedert JJ. Association of cancer with AIDSrelated immunosuppression in adults. JAMA 285: 1736-1745, 2001.

11 Mbulaiteye SM, Katabira ET, Henry H, et al. Spectrum of cancers among HIV-infected persons in Africa: The Uganda AIDS-Cancer Registry Match Study. Int J Cancer 118: 985-990, 2006.

12 Landriscina M, Fabiano A, Altamura S, et al. Reverse Transcriptase Inhibitors Down-Regulate Cell Proliferation in Vitro and in Vivo and Restore Thyrotropin Signaling and lodine Uptake in Human Thyroid Anaplastic Carcinoma. J Clin Endoc \& Metab 10: 5663-5671, 2005.

\section{Correspondence \\ Dr. Metin IȘIK}

Ankara Numune Eğitim ve Araştırma Hastanesi

Medikal Onkoloji Bölümü

06100 Sihhiye, ANKARA / TURKEY

Tel: (+90.312) 5084603

Fax: (+90.312) 5084600

e-mail: metin1721978@yahoo.com 